\title{
TEACHING IN THE XXI CENTURY
}

New information and communication technologies have stimulated the access to knowledge production and its dissemination. They had an important impact on all levels of social relationships leading to the super esteeming of knowledge. This means that knowledge and its acquisition processes will increasingly play a predominant role in the decisions about the society courses, especially when considering globalization. Presently, new ways of overcoming difficulties involves advanced technological, social and cultural correlations.

On the education field, at any level, the main aim should be the building of knowledge and the development of basic competences such as learning to search for information, understanding it, and creatively employing it in personal and social situations.

The intensive exploration of new technological resources introduced different ways of considering education in this world of knowledge. The increasing utilization of such resources in the classroom has generally helped to reduce the time needed for preparing the educational activity, making them a support tool for education. Adaptation to the new order is a consequence not only of the utilization but also of the optimization of those new technologies, which implies in reviewing the teaching and learning method, extending the discussion to beyond the simple act of employing technological artifacts in educational activities.

Today, more than never, the teacher is expected to have an attitude well-grounded on a constant process of reflection that could yield innovative results for education and lead to the creation of educative environments favoring the co-building of knowledge. In this scenario, teachers and students are stimulated to share the ethico-critical building process as participative and cooperative subjects.

Such change constitutes an impulse for the traditional conception of teaching to question the pedagogical projects and reformulate the roles played by their main actors.

To break the traditional barriers of an education based on vertical communication, which considers knowledge as an act of donation, is already a challenging landscape (1). 
The implantation of new technologies and all their transforming potential is thus needed as a new perspective of improvement in this third millennium. The wide and effective reformulation of the role of the conductor-teacher to a learner-teacher and pedagogical mediator, co-author in the production of knowledge, involves the stimulation of the students' autonomy, creating an environment where both are coparticipants in the teaching-learning process. From that environment should emerge possibilities to develop innovative abilities and competences for the new "savoirfaire", in a more conscious and critical way related to the context not only individual but also collective.

\section{REFERENCE}

1 FREIRE, Paulo. Pedagogia da Autonomia. Saberes necessários à prática educativa. São Paulo: Paz e Terra, 2003.

\section{CORRESPONDENCE TO:}

ELISABETH PERES BIRUEL, SciELO (Scientific Electronic Library Online), Centro Latino-Americano e do Caribe de Informação em Ciências da Saúde. BIREME/OPAS/OMS. São Paulo, SP, Brasil. Email: biruel@bireme.br. 